\title{
SYNTHESIS AND NEMATOCIDAL ACTIVITIES OF JIETACIN A AND ITS ANALOGS
}

\author{
Kazuo Tsuzuki, Fu-Shan Yan, Kazuhiko Otoguro \\ and SATOSHI OMURA* \\ Research Center for Biological Function, The Kitasato Institute, \\ and School of Pharmaceutical Sciences, Kitasato University, \\ Minato-ku, Tokyo 108, Japan
}

(Received for publication September 13, 1990)

\begin{abstract}
Simple, efficient syntheses of jietacin A, a nematocidal antibiotic, and its analogs have been developed in order to study structure-activity relationships. A series of $\alpha, \beta$-unsaturated azoxy compounds was prepared from phenylselenomethyl azoxy compounds as key intermediates and its nematocidal activity was determined.
\end{abstract}

As reported in the previous papers, ${ }^{1,2)}$ jietacins A (1) and B (2) produced by Streptomyces sp. KP-197 contain an unique vinylazoxy structure and show a potent activity against the pine wood nematode Bursaphelenchus lignicolus. We became interested in the participation of the characteristic vinylazoxy moiety of 1 in its prominent activity. In this paper we will describe the first total synthesis of $\mathbf{1}$ and the synthesis of azoxy analogs as well as their activities against $B$. lignicolus.

\section{Chemistry}

Our synthetic approach to 1 is outlined in Schemes 1 and 2. Aminoacetal 9, which corresponds

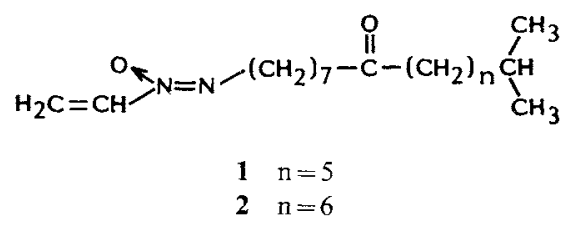

Scheme 1

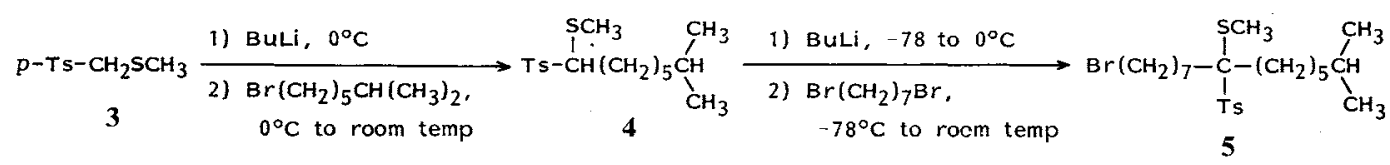

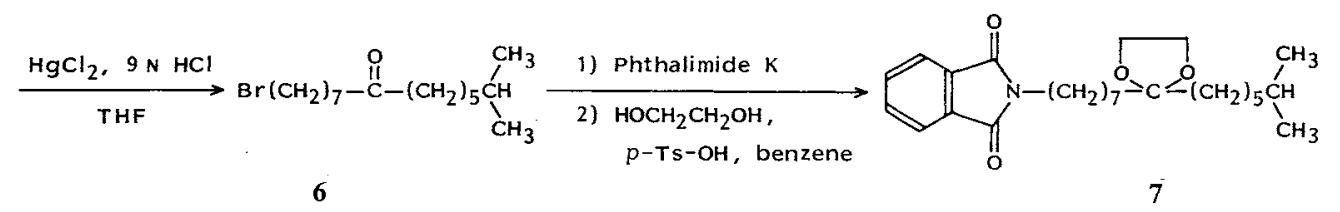<smiles>CCOC(N)CNCCCCCCCCCC(C)C</smiles> 
Scheme 2
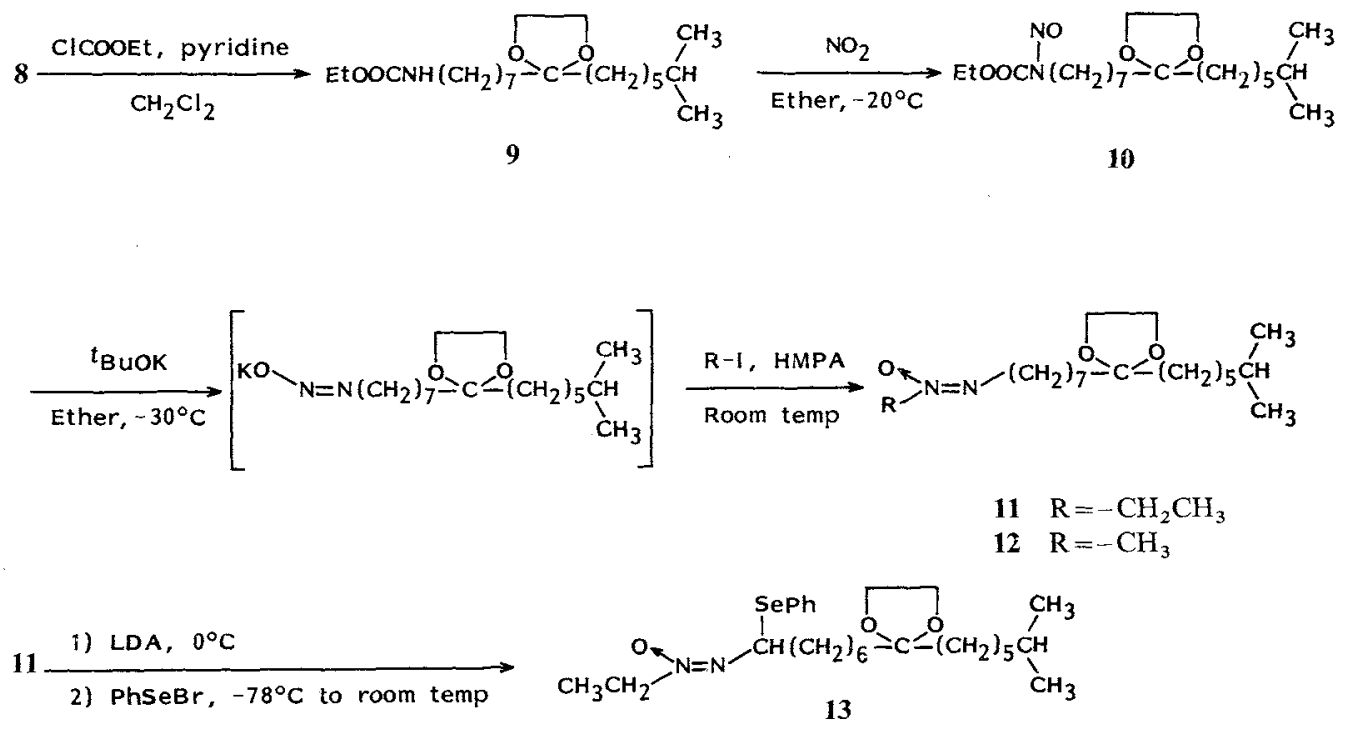

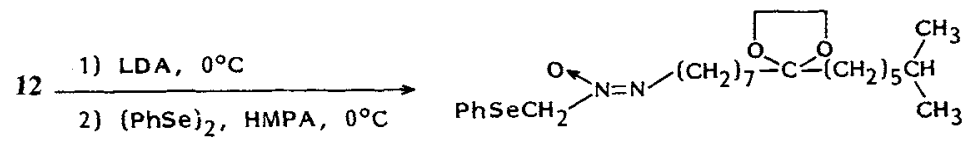

14

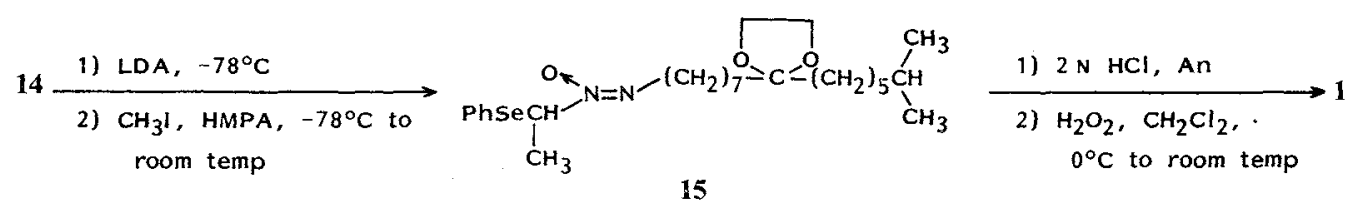<smiles>C=CN(N=NCCC(O)CCC(C)C)OCCO</smiles>

16

to an alkyl side chain of the azoxy group, was chosen for the most suitable intermediate by considering the structural feature of 1. Metalation of (methylthio)methyl $p$-tolyl sulfone (3) using $n$-butyllithium in tetrahydrofuran (THF) at $0^{\circ} \mathrm{C}$, followed by alkylation with 1-bromo-6-methylheptane, ${ }^{3)}$ gave 4 in $80 \%$ yield. Addition of $n$-butyllithium to a THF solution of 4 at $0^{\circ} \mathrm{C}$ in a similar manner as the first alkylation step resulted in decomposition of the substrate. A successful formation of carbanion of 4 was accomplished by the procedures that involved the careful addition of $n$-butyllithium to a well stirred THF solution of 4 at $-78^{\circ} \mathrm{C}$ and then warming the solution at $0^{\circ} \mathrm{C}$ to complete the deprotonation. The resulting anion 
was quenched by 1,7 -dibromoheptane at $-78^{\circ} \mathrm{C}$ to give 5 , which was directly hydrolyzed without purification using mercuric chloride and $9 \mathrm{~N} \mathrm{HCl}$ in THF at $0{ }^{\circ} \mathrm{C}$ to give 6 in $68 \%$ overall yield from 4 since the attempted isolation of 5 by column chromatography on silica gel resulted in contamination with 6. The conversion of 6 into primary amine 8 was performed by adopting the Gabriel synthesis, namely, succesive treatments including reaction with potassium phthalimide at $100^{\circ} \mathrm{C}$ in $N, N$-dimethylformamide, protection of a carbonyl group as an ethylene acetal and hydrazinolysis furnished $\mathbf{8}$ in $73 \%$ overall yield.

The preparation of the azoxy moiety was performed by a regioselective alkylation of a diazoate generalized by the treatment of the $N$-nitrosourethane with potassium tert-butoxide, according to the Moss's procedure. ${ }^{4)}$ Urethane 9 , which was obtained by reaction of 8 with ethyl chloroformate in dichloromethane $\left(\mathrm{CH}_{2} \mathrm{Cl}_{2}\right)$ in $90 \%$ yield, was treated with dinitrogen tetraoxide at $-20^{\circ} \mathrm{C}$ in ether to give $N$-nitrosourethane 10 . The cleavage of 10 with tert-butoxide in ether at $-30^{\circ} \mathrm{C}$, followed by trapping of the resulting diazoate anion with ethyl iodide and methyl iodide in hexamethylphosphoric triamide (HMPA) at room temperature gave 11 and $\mathbf{1 2}$, respectively, in $38 \%$ and $40 \%$ yield. Direct conversion of 11 into the vinylazoxy compound was attempted without success. Treatment of 11 with lithium diisopropylamide (LDA) in THF at $0^{\circ} \mathrm{C}$ and quenching of the generated anion with benzeneselenenyl bromide gave unfavorable $\alpha^{\prime}$-phenylseleno derivative 13. On the other hand, similar deprotonation of 12 with LDA $^{5)}$ and subsequent selenenylation with diphenyl diselenide in the presence of HMPA gave $\alpha$ phenylseleno derivative 14 regioselectively in $53 \%$ yield. Finally, 14 was employed in a straightforward construction of the characteristic vinylazoxy moiety of 1 . Selective deprotonation of 14 using LDA in THF at $-78^{\circ} \mathrm{C}$ and subsequent methylation of the generated anion with methyl iodide in the presence of HMPA gave 15 in $51 \%$ yield. Hydrolysis of the acetal function with $2 \mathrm{~N} \mathrm{HCl}$ in acetone, followed by oxidative elimination of the phenylseleno group by a two phase method (aqueous hydrogen peroxide $\left.\mathrm{CH}_{2} \mathrm{Cl}_{2}\right)$, ${ }^{6}$ furnished jietacin $\mathrm{A}(1)$ in $82 \%$ overall yield from 15 , spectral data $\left({ }^{1} \mathrm{H}\right.$ and ${ }^{23} \mathrm{C}$ NMR, IR, UV, MS) of which were identical in all respects with those of an authentic sample. Reduction of 1 with $\mathrm{NaBH}_{4}$ in ethanol at $0^{\circ} \mathrm{C}$ gave the alcohol 16 quantitatively.

Following these procedures, several jietacin analogs were synthesized. Alkylation of 14 with reactive alkyl halides such as ethyl iodide, allyl bromide, benzyl bromide and propargyl bromide gave the corresponding azoxy derivatives in $18 \sim$ $36 \%$ yield, which were converted to $\alpha, \beta$-unsaturated azoxyalkene 21, 22, 23 and 24 , respectively, in $80 \sim 82 \%$ overall yield. Starting from 6-methylheptylamine, 18 was obtained according to our established method.

\section{Results and Discussion}

Nematocidal activities ( $\mathrm{IC}_{50}$ values) of the syn-

Table 1. Nematocidal activities ( $\mathrm{IC}_{50}$ values) of jietacin A (1) and its analogs against Bursaphelenchus lignicolus.

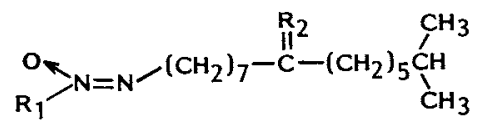

\begin{tabular}{|c|c|c|c|}
\hline & $\mathrm{R}_{1}$ & $\mathrm{R}_{2}$ & $\begin{array}{c}\mathrm{IC}_{50} \\
(\mu \mathrm{g} / \mathrm{ml})\end{array}$ \\
\hline $\begin{array}{r}\text { Jietacin } \\
\text { A (1) }\end{array}$ & $-\mathrm{CH}=\mathrm{CH}_{2}$ & $=\mathrm{O}$ & 0.038 \\
\hline 16 & $-\mathrm{CH}=\mathrm{CH}_{2}$ & $-\mathrm{OH},-\mathrm{H}$ & 0.08 \\
\hline 17 & $-\mathrm{CH}=\mathrm{CH}_{2}$ & 'o & 0.08 \\
\hline $18^{a}$ & $-\mathrm{CH}=\mathrm{CH}_{2}$ & - & 0.06 \\
\hline 19 & $-\mathrm{CH}_{3}$ & $=\mathrm{O}$ & 600 \\
\hline 20 & $-\mathrm{C}_{2} \mathrm{H}_{5}$ & $=\mathrm{O}$ & 4 \\
\hline 21 & (E) $-\mathrm{CH}=\mathrm{CH}-\mathrm{CH}_{3}$ & $=\mathrm{O}$ & 20 \\
\hline 22 & (E) $-\mathrm{CH}=\mathrm{CH}-\mathrm{CH}=\mathrm{CH}_{2}$ & $=0$ & 35 \\
\hline 23 & $(E)-\mathrm{CH}=\mathrm{CH}$ & $=0$ & 600 \\
\hline 24 & $(E)-\mathrm{CH}=\mathrm{CH}-\mathrm{C} \equiv \mathrm{CH}$ & $=\mathrm{O}$ & 0.3 \\
\hline
\end{tabular}


thesized azoxy compounds are summarized in Table 1. Modification of the vinyl group of 1 greatly diminished a nematocidal activity, while chemical change of the carbonyl function did not affect the activity. Moreover, the fact that $\mathbf{1 8}$ retained the activity comparable to that of jietacin may suggest that the alkyl side chain of 1 is not important for manifestation of nematocidal activity. It is noteworthy that 19 exhibited a considerably decreased activity compared with $\mathbf{2 0}$. The length of carbon chain may be another possible factor affecting the activity apart from unsaturated character. To summarize the results of the present study, we could establish a convergent synthetic method of jietacin $\mathrm{A}$ and its analogs. And their nematocidal activities clearly indicate that the vinylazoxy moiety is a responsible site for the potent activity of 1 .

\section{Experimental}

MP's were determined on a micro melting point apparatus (Yanaco MP-3). They were uncorrected. NMR spectra were run in $\mathrm{CDCl}_{3}$ on a $90 \mathrm{MHz}$ spectrometer (Jeol FX-90Q). IR spectra were taken on a Jasco A-102 spectrometer. Elemental analysis for carbon, hydrogen and nitrogen were determined with a Perkin-Elmer Model 240 elemental analyzer. Column chromatography was performed on Silica gel 60 (Art. No. 7734, Merck) and preparative TLC was performed on silica gel (Art. No. 13895, Merck).

\section{7-Methyl-1-methylthiooctyl p-Tolyl Sulfone (4)}

To a stirred solution of methylthiomethyl $p$-tolyl sulfone $3(10 \mathrm{~g}, 46.2 \mathrm{mmol})$ in dry THF $(100 \mathrm{ml})$ at $-78^{\circ} \mathrm{C}$ under nitrogen was added dropwise $33 \mathrm{ml}(50.5 \mathrm{mmol})$ of $1.53 \mathrm{M} n$-butyllithium in hexane. After the addition was complete, the solution was stirred at $-78^{\circ} \mathrm{C}$ for further 10 minutes and then warmed to $0^{\circ} \mathrm{C}$ for 30 minutes, a solution of 6-methyl-1-bromoheptane $(11 \mathrm{~g}, 57.0 \mathrm{mmol})$ in THF $(10 \mathrm{ml})$ was added dropwise. After the addition was complete, the reaction mixture was allowed to warm to room temperature gradually. After 12 hours, the mixture was diluted with $\mathrm{CH}_{2} \mathrm{Cl}_{2}$, washed with $2 \mathrm{~N} \mathrm{HCl}$, dried over $\mathrm{Na}_{2} \mathrm{SO}_{4}$, and concentrated in vacuo. The residue was purified by column chromatography on silica gel, eluting with hexane - ethyl acetate (20:1) to afford $12 \mathrm{~g} \mathrm{(79 \% )} \mathrm{of} 4$ as a colorless oil: IR (neat) $\mathrm{cm}^{-1} 3025,2950,2925$, 2860,$1598 ;{ }^{1} \mathrm{H} \mathrm{NMR}\left(\mathrm{CDCl}_{3}\right) \delta 0.85(6 \mathrm{H}, \mathrm{d}, J=6.1 \mathrm{~Hz}), 2.22(3 \mathrm{H}, \mathrm{s}), 2.45(3 \mathrm{H}, \mathrm{s}), 3.65(1 \mathrm{H}, \mathrm{dd}, J=10.3$ and $2.9 \mathrm{~Hz}), 7.35(2 \mathrm{H}, \mathrm{d}, J=8.2 \mathrm{~Hz}), 7.83(2 \mathrm{H}, \mathrm{d}, J=8.2 \mathrm{~Hz}) ; \mathrm{MS} m / z 328\left(\mathrm{M}^{+}\right)$.

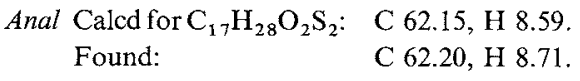

1-Bromo-14-methyl-8-pentadecanone (6)

To a stirred solution of $4(5 \mathrm{~g}, 15.2 \mathrm{mmol})$ in THF $(50 \mathrm{ml})$ at $-78^{\circ} \mathrm{C}$ under nitrogen was added dropwise over 30 minutes $11 \mathrm{ml}(16.8 \mathrm{mmol})$ of $1.53 \mathrm{M} n$-butyllithium in hexane. After the addition was complete, the solution was stirred at $-78^{\circ} \mathrm{C}$ for 5 minutes and then warmed to $0^{\circ} \mathrm{C}$. After the stirring was continued for 20 minutes at $0^{\circ} \mathrm{C}$, the solution was cooled at $-78^{\circ} \mathrm{C}$ again. A solution of 1,7 -dibromoheptane $(4.7 \mathrm{~g}, 18.2 \mathrm{mmol})$ in THF $(5 \mathrm{ml})$ was added and the resulting mixture was allowed to warm to room temperature gradually. After 12 hours, the mixture was diluted with $\mathrm{CH}_{2} \mathrm{Cl}_{2}$, washed with $2 \mathrm{~N} \mathrm{HCl}$, dried $\left(\mathrm{Na}_{2} \mathrm{SO}_{4}\right)$, and concentrated in vacuo to leave 1-bromo-14-methyl-8-methylthio-8-pentadecanyl $p$-tolyl sulfone (5) as a slightly yellow oil. To a stirred solution of $\mathrm{HgCl}_{2}(1.6 \mathrm{~g}, 58.9 \mathrm{mmol})$ in $9 \mathrm{~N} \mathrm{HCl}(6 \mathrm{ml})$ and THF $(24 \mathrm{ml})$ at $0^{\circ} \mathrm{C}$ was added a solution of the crude 5 in THF $(3 \mathrm{ml})$. After stirring at $0^{\circ} \mathrm{C}$ for 1.5 hours, the mixture was extracted with $\mathrm{CH}_{2} \mathrm{Cl}_{2}$. The extracts were dried $\left(\mathrm{Na}_{2} \mathrm{SO}_{4}\right)$ and concentrated in vacuo. The residue was purified by column chromatograhy on silica gel, eluting with hexane-ethyl acetate (20:1) to afford $3.3 \mathrm{~g}(68 \%)$ of 6 as a colorless oil: IR (neat) $\mathrm{cm}^{-1} 2940,2860,1715 ;{ }^{1} \mathrm{H} \mathrm{NMR}\left(\mathrm{CDCl}_{3}\right)$ $\delta 0.86(6 \mathrm{H}, \mathrm{d}, J=6.1 \mathrm{~Hz}), 2.39(4 \mathrm{H}, \mathrm{t}, J=7.1 \mathrm{~Hz}), 3.40(2 \mathrm{H}, \mathrm{t}, J=6.7 \mathrm{~Hz}) ; \mathrm{MS} m / z 239\left(\mathrm{M}^{+}-\mathrm{Br}\right)$.

Anal Calcd for $\mathrm{C}_{16} \mathrm{H}_{31} \mathrm{BrO}: \quad \mathrm{C} 60.18, \mathrm{H} 9.78$. Found: $\quad$ C 60.04, H 9.78 .

$N$-(8,8-Ethylenedioxy-14-methylpentadecanyl)phthalimide (7)

A solution of $6(6 \mathrm{~g}, 18.8 \mathrm{mmol})$ and potassium phthalimide $(5.2 \mathrm{~g}, 28.1 \mathrm{mmol})$ in DMF $(100 \mathrm{ml})$ was heated to $100^{\circ} \mathrm{C}$ for 15 hours. The mixture was concentrated in vacuo and the residue was diluted in 
$\mathrm{CH}_{2} \mathrm{Cl}_{2}$. The solution was washed with water, dried $\left(\mathrm{Na}_{2} \mathrm{SO}_{4}\right)$ and concentrated in vacuo. A solution of the resulting crude $N$-(14-methyl-8-pentadecanonyl)phthalimide, ethylene glycol $(3.5 \mathrm{~g}, 56.4 \mathrm{mmol})$ and $p$-toluenesulfonic acid monohydrate $(300 \mathrm{mg}, 1.58 \mathrm{mmol})$ in benzene $(100 \mathrm{ml})$ was heated at reflux under a Dean-Stark trap for 20 hours. The mixture was washed with saturated $\mathrm{NaHCO}_{3}$ aqueous solution, dried $\left(\mathrm{Na}_{2} \mathrm{SO}_{4}\right)$ and concentrated in vacuo. The residue was purified by column chromatography on silica gel, eluting with hexane - ethyl acetate $(10: 1)$ to afford $6.2 \mathrm{~g}(77 \%)$ of 7 as a colorless oil: IR (neat) $\mathrm{cm}^{-1}$ 2930, 2860, 1770, 1710, 1607; ${ }^{1} \mathrm{H}$ NMR $\left(\mathrm{CDCl}_{3}\right) \delta 0.86(6 \mathrm{H}, \mathrm{d}, J=6.1 \mathrm{~Hz}), 3.68(2 \mathrm{H}, \mathrm{t}, J=7.0 \mathrm{~Hz}), 3.92$ $(4 \mathrm{H}, \mathrm{s}), 7.77(4 \mathrm{H}, \mathrm{m})$; MS $m / z 386\left(\mathrm{M}^{+}-\mathrm{C}_{3} \mathrm{H}_{7}\right)$.

Anal Calcd for $\mathrm{C}_{26} \mathrm{H}_{39} \mathrm{NO}_{4}$ : C 72.69, H 9.15, N 3.26.

Found:

C $72.51, \mathrm{H} 9.09, \mathrm{~N} 3.09$.

Ethyl 8,8-Ethylenedioxy-14-methylpentadecanyl Carbamate (9)

A solution of $7(2 \mathrm{~g}, 4.66 \mathrm{mmol})$ and $80 \%$ hydrazine monohydrate $(0.3 \mathrm{ml}, 4.84 \mathrm{mmol})$ in EtOH $(15 \mathrm{ml})$ was heated at reflux for 1.5 hours. The reaction mixture began to solidify within 15 minutes from the start of refluxing. The mixture was cooled to room temperature and $\mathrm{CH}_{2} \mathrm{Cl}_{2}(15 \mathrm{ml})$ and $3 \mathrm{~N} \mathrm{KOH}(8 \mathrm{ml})$ were added with stirring. The suspension began to be separated into two clear layers. The aqueous layer was extracted with $\mathrm{CH}_{2} \mathrm{Cl}_{2}$. The combined organic layers were dried $\left(\mathrm{Na}_{2} \mathrm{SO}_{4}\right)$ and concentrated in vacuo to afford 8,8-ethylenedioxy-14-methylpentadecanamine (8) as a colorless oil. 8: IR (neat) $\mathrm{cm}^{-1} 3320,2930$, 2850, 1570; ${ }^{1} \mathrm{H} \mathrm{NMR}\left(\mathrm{CDCl}_{3}\right) \delta 0.86(6 \mathrm{H}, \mathrm{d}, J=6.1 \mathrm{~Hz}), 2.26(2 \mathrm{H}, \mathrm{m}), 2.67(2 \mathrm{H}, \mathrm{m}), 3.92(4 \mathrm{H}, \mathrm{s}) ; \mathrm{MS}$ $m / z 186\left(\mathrm{M}^{+}-\mathrm{C}_{8} \mathrm{H}_{17}\right), 185\left(\mathrm{M}^{+}-\mathrm{C}_{7} \mathrm{H}_{16} \mathrm{~N}\right)$.

The crude product was dissolved in $\mathrm{CHCl}_{3}(10 \mathrm{ml})$. To the stirred solution at $0^{\circ} \mathrm{C}$ were added pyridine $(0.57 \mathrm{ml}, 7.05 \mathrm{mmol})$ and ethyl chloroformate $(0.54 \mathrm{ml}, 5.65 \mathrm{mmol})$. Stirring was continued for 1 hour and then the mixture was poured into ice-saturated $\mathrm{NaHCO}_{3}$ aqueous solution. The product was extracted with $\mathrm{CH}_{2} \mathrm{Cl}_{2}$, dried $\left(\mathrm{Na}_{2} \mathrm{SO}_{4}\right)$ and concentrated in vacuo. The residue was purified by column chromatography on silica gel, eluting with hexane-ethyl acetate $(10: 1)$ to afford $1.6 \mathrm{~g}(93 \%)$ of 9 as a colorless oil. IR (neat) $\mathrm{cm}^{-1}, 3340,2930,2860,1700 ;{ }^{1} \mathrm{H} \mathrm{NMR}\left(\mathrm{CDCl}_{3}\right) \delta 0.86(6 \mathrm{H}, \mathrm{d}, J=6.1 \mathrm{~Hz}), 1.23$ $(3 \mathrm{H}, \mathrm{t}, J=7.1 \mathrm{~Hz}), 3.14(2 \mathrm{H}, \mathrm{br} \mathrm{q}, J=6.4 \mathrm{~Hz}), 3.92(4 \mathrm{H}, \mathrm{s}), 4.10(2 \mathrm{H}, \mathrm{q}, J=7.1 \mathrm{~Hz}), 4.77(1 \mathrm{H}$, br t $)$; MS $m / z 328\left(\mathrm{M}^{+}-\mathrm{C}_{3} \mathrm{H}_{7}\right)$.

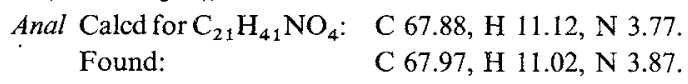

\section{8,8-Ethylenedioxy-14-methyl-1-(methyl- $O, N, N$-azoxy)pentadecane (12)}

To a vigorously stirred suspension of $9(3 \mathrm{~g}, 8.07 \mathrm{mmol})$ and $\mathrm{NaHCO}_{3}(6 \mathrm{~g}, 71.4 \mathrm{mmol})$ in dry ethyl ether $(15 \mathrm{ml})$ at $-40^{\circ} \mathrm{C}$ under nitrogen was added dropwise a solution of $\mathrm{N}_{2} \mathrm{O}_{4}(5.5 \mathrm{~g}, 59.8 \mathrm{mmol})$ in ethyl ether $(4 \mathrm{ml})$. After the addition was complete, the reaction mixture was stirred at $-20^{\circ} \mathrm{C}$ for 30 minutes and then poured into ice-saturated $\mathrm{NaHCO}_{3}$ aqueous solution. The ethereal layer was separated, dried $\left(\mathrm{Na}_{2} \mathrm{SO}_{4}\right)$ and concentrated in vacuo under $30^{\circ} \mathrm{C}$ to afford the $N$-nitroso product (10) as yellow oil, which was stored at $-80^{\circ} \mathrm{C}$ and was used for the next reaction without further purification. To a suspension of potassium tert-butoxide $(1.36 \mathrm{~g}, 12.1 \mathrm{mmol})$ in ethyl ether $(20 \mathrm{ml})$ at $-40^{\circ} \mathrm{C}$ under nitrogen was added dropwise a solution of the $N$-nitroso product in ethyl ether $(6 \mathrm{ml})$. After the mixture was stirred at $-25^{\circ} \mathrm{C}$ for 1 hour, the solvent was removed under $0^{\circ} \mathrm{C}$ in vacuo. To the residue were added HMPA $(20 \mathrm{ml})$ and methyl iodide $(5 \mathrm{ml}, 80.3 \mathrm{mmol})$ and then the resulting mixture was stirred at room temperature for 20 hours. The solvents were removed in vacuo and the residue was diluted with $\mathrm{CH}_{2} \mathrm{Cl}_{2}$. The solution was washed with water, dried $\left(\mathrm{Na}_{2} \mathrm{SO}_{4}\right)$ and concentrated in vacuo. The residue was purified by column chromatography on silica gel, eluting with hexane - ethyl acetate $(10: 1)$ to afford $1.1 \mathrm{~g}(40 \%)$ of 12 as a slightly yellow oil: IR (neat) $\mathrm{cm}^{-1} 2910,2850,1510 ;{ }^{1} \mathrm{H}$ NMR $\left(\mathrm{CDCl}_{3}\right) \delta 0.86(6 \mathrm{H}, \mathrm{d}, J=6.1 \mathrm{~Hz}), 3.39$ $(2 \mathrm{H}$, br t,$J=6.9 \mathrm{~Hz}), 3.92(4 \mathrm{H}, \mathrm{s}), 4.06(3 \mathrm{H}, \mathrm{t}, J=1.5 \mathrm{~Hz})$; MS $m / z 325\left(\mathrm{M}^{+}-\mathrm{OH}\right)$.

Anal Calcd for $\mathrm{C}_{19} \mathrm{H}_{38} \mathrm{~N}_{2} \mathrm{O}_{3}$ : C 66.63, $\mathrm{H} 11.18, \mathrm{~N} 8.18$. Found: C 66.56, H 11.11, N 8.10.

8,8-Ethylenedioxy-14-methyl-1-(phenylselenomethyl- $O, N, N$-azoxy)pentadecane (14)

A solution of LDA was prepared by adding $2 \mathrm{ml}(3.28 \mathrm{mmol})$ of $1.64 \mathrm{M} n$-butyllithium in hexane to diisopropylamine $(0.45 \mathrm{ml}, 3.21 \mathrm{mmol})$ in THF $(4 \mathrm{ml})$. The solution was stirred and cooled to $0^{\circ} \mathrm{C}$, and a 
solution of $12(1 \mathrm{~g}, 2.92 \mathrm{mmol})$ in THF ( $2 \mathrm{ml})$ was added. After 30 minutes, a solution of diphenyl diselenide $(1.37 \mathrm{~g}, 4.39 \mathrm{mmol})$ and HMPA $(1 \mathrm{ml}, 5.75 \mathrm{mmol})$ in THF $(1 \mathrm{ml})$ was added to the resulting solution of the carbanion. Stirring was continued for 90 minutes at $0^{\circ} \mathrm{C}$. The reaction mixture was diluted with $\mathrm{CH}_{2} \mathrm{Cl}_{2}$, washed with saturated $\mathrm{NH}_{4} \mathrm{Cl}$ aqueous solution, dried $\left(\mathrm{Na}_{2} \mathrm{SO}_{4}\right)$, and concentrated in vacuo. The residue was purified by column chromatography on silica gel, eluting with hexane - ethyl acetate $(10: 1)$ to afford $772 \mathrm{mg}(53 \%)$ of 14 as a slightly yellow oil: IR (neat) $\mathrm{cm}^{-1} 3070,2950,2880,1580,1502 ;{ }^{1} \mathrm{H}$ NMR $\left(\mathrm{CDCl}_{3}\right) \delta 0.86(6 \mathrm{H}, \mathrm{d}, J=6.4 \mathrm{~Hz}), 3.36(2 \mathrm{H}, \mathrm{t}, J=6.7 \mathrm{~Hz}), 3.92(4 \mathrm{H}, \mathrm{s}), 5.40(2 \mathrm{H}, \mathrm{s}), 7.3(3 \mathrm{H}, \mathrm{m}), 7.6$ $(2 \mathrm{H}, \mathrm{m}) ; \mathrm{MS} m / z 385\left(\mathrm{M}^{+}-\mathrm{C}_{8} \mathrm{H}_{17}\right)$.

Anal Calcd for $\mathrm{C}_{25} \mathrm{H}_{42} \mathrm{~N}_{2} \mathrm{O}_{3} \mathrm{Se}:$ C 60.35, H 8.51, N 5.63 . Found:

C $60.28, \mathrm{H} 8.47, \mathrm{~N} 5.72$.

8,8-Ethylenedioxy-14-methyl-1-(1-phenylselenoethyl- $O, N, N$-azoxy)pentadecane (15)

A solution of LDA prepared from $1.25 \mathrm{ml}(1.91 \mathrm{mmol})$ of $1.53 \mathrm{M} n$-butyllithium in hexane and diisopropylamine $(0.27 \mathrm{ml}, 1.93 \mathrm{mmol})$ in THF $(2.5 \mathrm{ml})$ was cooled to $-78^{\circ} \mathrm{C}$ and a solution of $14(860 \mathrm{mg}$, $1.73 \mathrm{mmol})$ in THF $(1 \mathrm{ml})$ was added dropwise. After 1 hour, HMPA $(0.3 \mathrm{ml}, 1.72 \mathrm{mmol})$ and methyl iodide $(0.32 \mathrm{ml}, 5.14 \mathrm{mmol})$ were added. After stirring at $-78^{\circ} \mathrm{C}$ for 1 hour, the mixture was allowed to warm up to room temperature. After 20 hours the mixture was diluted with $\mathrm{CH}_{2} \mathrm{Cl}_{2}$, washed with saturated $\mathrm{NH}_{4} \mathrm{Cl}$ aqueous solution, dried $\left(\mathrm{Na}_{2} \mathrm{SO}_{4}\right)$ and concentrated in vacuo. The residue was purified by column chromatography on silica gel, eluting with hexane - ethyl acetate $(10: 1)$ to afford $450 \mathrm{mg}(51 \%)$ of 15 as a slightly yellow oil: IR (neat) $\mathrm{cm}^{-1} 3050,2910,2850,1575,1498 ;{ }^{1} \mathrm{H} \mathrm{NMR}\left(\mathrm{CDCl}_{3}\right) \delta 0.86(6 \mathrm{H}, \mathrm{d}$, $J=6.1 \mathrm{~Hz}), 1.84(3 \mathrm{H}, \mathrm{d}, J=7.1 \mathrm{~Hz}), 3.30(2 \mathrm{H}, \mathrm{t}, J=6.9 \mathrm{~Hz}), 3.92(4 \mathrm{H}, \mathrm{s}), 5.64(1 \mathrm{H}, \mathrm{q}, J=7.1 \mathrm{~Hz}), 7.3(3 \mathrm{H}$, $\mathrm{m}), 7.6(2 \mathrm{H}, \mathrm{m}) ; \mathrm{MS} m / z 399\left(\mathrm{M}^{+}-\mathrm{C}_{8} \mathrm{H}_{17}\right)$.

Anal Calcd for $\mathrm{C}_{26} \mathrm{H}_{44} \mathrm{~N}_{2} \mathrm{O}_{3} \mathrm{Se}: \quad \mathrm{C} 61.04, \mathrm{H} 8.67, \mathrm{~N} 5.48$. Found:

C 60.84, H 8.70, N 5.59 .

\section{Jietacin A (1)}

To a solution of $15(670 \mathrm{mg}, 1.31 \mathrm{mmol})$ in acetone $(5 \mathrm{ml})$ was added $2 \mathrm{~N} \mathrm{HCl}(0.5 \mathrm{ml})$ and the resulting mixture was stirred for 30 minutes at room temperature. After the mixture was neutralized with saturated $\mathrm{NaHCO}_{3}$ aqueous solution, the product was extracted with $\mathrm{CH}_{2} \mathrm{Cl}_{2}$. The extracts were dried $\left(\mathrm{Na}_{2} \mathrm{SO}_{4}\right)$ and concentrated in vacuo. The residue was diluted with $\mathrm{CH}_{2} \mathrm{Cl}_{2}(5 \mathrm{ml})$ and cooled to $0^{\circ} \mathrm{C}$. To the stirred solution was added $35 \% \mathrm{H}_{2} \mathrm{O}_{2}(0.5 \mathrm{mi})$. The resulting mixture was stirred for 30 minutes at $0^{\circ} \mathrm{C}$, warmed to room temperature, and stirred for 2 hours. After addition of water, the product was extracted with $\mathrm{CH}_{2} \mathrm{Cl}_{2}$. The extracts were dried $\left(\mathrm{Na}_{2} \mathrm{SO}_{4}\right)$ and concentrated in vacuo. The residue was purified by column chromatography on silica gel, eluting with hexane - ethyl acetate $(10: 1)$ to afford $3.35 \mathrm{mg}(82 \%)$ of jietacin A (1), mp $39^{\circ} \mathrm{C}$ as white crystals: Spectrai data $\left({ }^{1} \mathrm{H}\right.$ and ${ }^{13} \mathrm{C}$ NMR, IR, UV, mass spectral) were identical in all respects with those of an authentic sample. ${ }^{1,2)}$

\section{8,8-Ethylenedioxy-14-methyl-1-(1-phenylselenopropyl- $O, N, N$-azoxy)pentadecane (25)}

A solution of LDA prepared from $0.265 \mathrm{ml}(0.42 \mathrm{mmol})$ of $1.64 \mathrm{M} n$-butyllithium in hexane and diisopropylamine $(0.061 \mathrm{ml}, 0.44 \mathrm{mmol})$ in THF $(0.5 \mathrm{ml})$ was cooled to $-78^{\circ} \mathrm{C}$ and a solution of $14(195 \mathrm{mg}$, $0.39 \mathrm{mmol})$ in THF $(0.4 \mathrm{ml})$ was added dropwise. After 1 hour, HMPA $(0.137 \mathrm{ml}, 0.79 \mathrm{mmol})$ and ethyl bromide $(0.09 \mathrm{ml}, 1.21 \mathrm{mmol})$ were added. After stirring at $-78^{\circ} \mathrm{C}$ for 1 hour, the mixture was allowed to warm up to room temperature. After 20 hours the mixture was diluted with $\mathrm{CH}_{2} \mathrm{Cl}_{2}$, washed with saturated $\mathrm{NH}_{4} \mathrm{Cl}$ aqueous solution, dried $\left(\mathrm{Na}_{2} \mathrm{SO}_{4}\right)$ and concentrated in vacuo. The residue was purified by column chromatography on silica gel, eluting with hexane - ethyl acetate $(10: 1)$ to afford $36 \mathrm{mg}$ of 14 and $75 \mathrm{mg}(36 \%)$ of 25 as a slightly yellow oil: IR (neat) $\mathrm{cm}^{-1} 3075,2940,2870,1580,1502 ;{ }^{1} \mathrm{H}$ NMR $\left(\mathrm{CDCl}_{3}\right) \delta 0.86(6 \mathrm{H}, \mathrm{d}, J=6.1 \mathrm{~Hz}), 0.98(3 \mathrm{H}, \mathrm{t}, J=7.4 \mathrm{~Hz}), 2.11(2 \mathrm{H}, \mathrm{m}), 3.32(2 \mathrm{H}, \mathrm{t}, J=6.6 \mathrm{~Hz}), 3.92$ $(4 \mathrm{H}, \mathrm{s}), 5.41(1 \mathrm{H}, \mathrm{dd}, J=8.8$ and $6.1 \mathrm{~Hz}), 7.3(3 \mathrm{H}, \mathrm{m}), 7.6(2 \mathrm{H}, \mathrm{m}) ; \mathrm{MS} m / z 526\left(\mathrm{M}^{+}\right)$.

$$
\begin{array}{ll}
\begin{array}{l}
\text { Anal Calcd for } \mathrm{C}_{27} \mathrm{H}_{46} \mathrm{~N}_{2} \mathrm{O}_{3} \mathrm{Se}: \\
\text { Found: }
\end{array} & \mathrm{C} 61.70, \mathrm{H} 8.82, \mathrm{~N} 5.33 . \\
& \mathrm{C} 61.74, \mathrm{H} 8.88, \mathrm{~N} 5.45 .
\end{array}
$$

14-Methyl-1-(1-propenyl- $O, N, N$-azoxy)-8-pentadecanone (21)

To a solution of $25(74 \mathrm{mg}, 0.14 \mathrm{mmol})$ in acetone $(2 \mathrm{ml})$ was added $2 \mathrm{~N} \mathrm{HCl}(0.5 \mathrm{ml})$ and the resulting mixture was stirred for 30 minutes at room temperature. After the mixture was neutralized with saturated 
$\mathrm{NaHCO}_{3}$ aqueous solution, the product was extracted with $\mathrm{CH}_{2} \mathrm{Cl}_{2}$. The extracts were dried $\left(\mathrm{Na}_{2} \mathrm{SO}_{4}\right)$ and concentrated in vacuo. The residue was diluted with $\mathrm{CH}_{2} \mathrm{Cl}_{2}(2 \mathrm{ml})$ and cooled to $0^{\circ} \mathrm{C}$. To the stirred solution was added $35 \% \mathrm{H}_{2} \mathrm{O}_{2}(0.3 \mathrm{ml})$. The resulting mixture was stirred for 30 minutes at $0^{\circ} \mathrm{C}$, warmed to room temperature, and stirred for 2 hours. After addition of water, the product was extracted with $\mathrm{CH}_{2} \mathrm{Cl}_{2}$. The extracts were dried $\left(\mathrm{Na}_{2} \mathrm{SO}_{4}\right)$ and concentrated in vacuo. The residue was purified by preparative TLC on silica gel, developing with hexane - ethyl acetate $(10: 1)$ to afford $37 \mathrm{mg}(81 \%)$ of 21 , $\mathrm{mp} 50 \sim 51^{\circ} \mathrm{C}$ as white crystals: IR (neat) $\mathrm{cm}^{-1} 3100,2930,2870,1705,1465 ;{ }^{1} \mathrm{H}$ NMR $\left(\mathrm{CDCl}_{3}\right) \delta 0.86$ $(6 \mathrm{H}, \mathrm{d}, J=6.1 \mathrm{~Hz}), 1.87(3 \mathrm{H}, \mathrm{d}, J=5.2 \mathrm{~Hz}), 2.39(4 \mathrm{H}, \mathrm{t}, J=7.0 \mathrm{~Hz}), 3.51(2 \mathrm{H}, \mathrm{t}, J=6.7 \mathrm{~Hz}), 7.0(2 \mathrm{H}, \mathrm{m})$; MS $m / z 307\left(\mathbf{M}^{+}-17\right)$.

Anal Caled for $\mathrm{C}_{19} \mathrm{H}_{36} \mathrm{~N}_{2} \mathrm{O}_{2}$ : C 70.33, $\mathrm{H} 11.18, \mathrm{~N} 8.63$.

Found: $\quad \mathrm{C} 70.17, \mathrm{H} 11.15, \mathrm{~N} 8.68$

8,8-Ethylenedioxy-14-methyl-1-(1-phenylseleno-3-butenyl- $O, N, N$-azoxy)pentadecane (26)

A solution of LDA prepared from $0.24 \mathrm{ml}(0.39 \mathrm{mmol})$ of $1.64 \mathrm{M} n$-butyllithium in hexane and diisopropylamine $(0.056 \mathrm{ml}, 0.40 \mathrm{mmol})$ in THF $(1 \mathrm{ml})$ was cooled to $-78^{\circ} \mathrm{C}$ and a solution of $14(181 \mathrm{mg}$, $0.36 \mathrm{mmol})$ in THF $(0.8 \mathrm{ml})$ was added dropwise. After 1 hour, HMPA $(0.127 \mathrm{ml}, 0.73 \mathrm{mmol})$ and allyl bromide $(0.1 \mathrm{ml}, 1.16 \mathrm{mmol})$ were added. After stirring at $-78^{\circ} \mathrm{C}$ for 1 hour, the mixture was allowed to warm up to room temperature. After 3 hours, the mixture was diluted with $\mathrm{CH}_{2} \mathrm{Cl}_{2}$, washed with saturated $\mathrm{NH}_{4} \mathrm{Cl}$ aqueous solution, dried $\left(\mathrm{Na}_{2} \mathrm{SO}_{4}\right)$ and concentrated in vacuo. The residue was purified by preparative TLC on silica gel, developing with hexane - ethyl acetate (10:1) to afford $27 \mathrm{mg}$ of 14 and $67 \mathrm{mg} \mathrm{(34 \% )}$ of 26 as a slightly yellow oil: IR (neat) $\mathrm{cm}^{-1} 3070,2940,2870,1642,1580,1500 ;{ }^{1} \mathrm{H}$ NMR $\left(\mathrm{CDCl}_{3}\right) \delta$ $0.86(6 \mathrm{H}, \mathrm{d}, J=6.1 \mathrm{~Hz}), 2.8(2 \mathrm{H}, \mathrm{m}), 3.30(2 \mathrm{H}, \mathrm{t}, J=6.6 \mathrm{~Hz}), 3.92(4 \mathrm{H}, \mathrm{s}), 5.51(1 \mathrm{H}, \mathrm{dd}, J=8.8$ and $6.1 \mathrm{~Hz})$, $5.7(3 \mathrm{H}, \mathrm{m}), 7.3(3 \mathrm{H}, \mathrm{m}), 7.6(2 \mathrm{H}, \mathrm{m}) ; \mathrm{MS} m / z 538\left(\mathrm{M}^{+}\right)$.

Anal Calcd for $\mathrm{C}_{28} \mathrm{H}_{46} \mathrm{~N}_{2} \mathrm{O}_{3} \mathrm{Se}:$ C 62.55, H 8.62, N 5.21. Found:

C 62.45, H 8.62, N 5.36.

14-Methyl-1-(1,3-butadienyl- $O, N, N$-azoxy)-8-pentadecanone (22)

To a solution of $26(86 \mathrm{mg}, 0.16 \mathrm{mmol})$ in acetone $(2 \mathrm{ml})$ was added $2 \mathrm{~N} \mathrm{HCl}(0.2 \mathrm{ml})$ and the resulting mixture was stirred for 30 minutes at room temperature. After the mixture was neutralized with saturated $\mathrm{NaHCO}_{3}$ aqueous solution, the product was extracted with $\mathrm{CH}_{2} \mathrm{Cl}_{2}$. The extracts were dried $\left(\mathrm{Na}_{2} \mathrm{SO}_{4}\right)$ and concentrated in vacuo. The residue was diluted with $\mathrm{CH}_{2} \mathrm{Cl}_{2}(2 \mathrm{ml})$ and cooled to $0^{\circ} \mathrm{C}$. To the stirred solution was added $35 \% \mathrm{H}_{2} \mathrm{O}_{2}(0.3 \mathrm{ml})$. The resulting mixture was stirred for 30 minutes at $0^{\circ} \mathrm{C}$, warmed to room temperature, and stirred for 2 hours. After addition of water, the product was extracted with $\mathrm{CH}_{2} \mathrm{Cl}_{2}$. The extracts were dried $\left(\mathrm{Na}_{2} \mathrm{SO}_{4}\right)$ and concentrated in vacuo. The residue was purified by preparative TLC on silica gel, developing with hexane - ethyl acetate $(10: 1)$ to afford $44 \mathrm{mg}(82 \%)$ of $\mathbf{2 2}$, mp 53 54 ${ }^{\circ} \mathrm{C}$ as white crystals: IR (neat) $\mathrm{cm}^{-1} 3080,2930,2850,1702,1600,1460 ;{ }^{1} \mathrm{H}$ NMR $\left(\mathrm{CDCl}_{3}\right) \delta$ $0.86(6 \mathrm{H}, \mathrm{d}, J=6.1 \mathrm{~Hz}), 2.39(4 \mathrm{H}, \mathrm{t}, J=7.0 \mathrm{~Hz}), 3.54(2 \mathrm{H}, \mathrm{t}, J=6.7 \mathrm{~Hz}), 5.52(1 \mathrm{H}, \mathrm{d}, J=10.2 \mathrm{~Hz}), 5.66$ $(1 \mathrm{H}, \mathrm{dd}, J=16.9 \mathrm{~Hz}), 6.46(1 \mathrm{H}, \mathrm{dt}, J=16.9$ and $10.2 \mathrm{~Hz}), 7.08(1 \mathrm{H}, \mathrm{d}, J=13.3 \mathrm{~Hz}), 7.40(1 \mathrm{H}, \mathrm{dd}, J=13.3$ and $10.2 \mathrm{~Hz})$; MS $m / z 319\left(\mathrm{M}^{+}-\mathrm{OH}\right)$.

Anal Calcd for $\mathrm{C}_{20} \mathrm{H}_{36} \mathrm{~N}_{2} \mathrm{O}_{2}: \quad \mathrm{C} 71.38, \mathrm{H} 10.78, \mathrm{~N} 8.32$.

Found: $\quad$ C $71.42, \mathrm{H} 70.80, \mathrm{~N} 8.11$

8,8-Ethylenedioxy-14-methyl-1-(1-phenylseleno-3-butynyl- $O, N, N$-azoxy)pentadecane (27)

A solution of LDA prepared from $0.25 \mathrm{ml}(0.41 \mathrm{mmol})$ of $1.64 \mathrm{M} n$-butyllithium in hexane and diisopropylamine $(0.058 \mathrm{ml}, 0.41 \mathrm{mmol})$ in THF $(0.5 \mathrm{ml})$ was cooled to $-78^{\circ} \mathrm{C}$ and a solution of $14(186 \mathrm{mg}$, $0.37 \mathrm{mmol})$ in THF $(0.4 \mathrm{ml})$ was added dropwise. After 1 hour, HMPA $(0.13 \mathrm{ml}, 0.75 \mathrm{mmol})$ and propargyl bromide $(0.1 \mathrm{ml}, 1.12 \mathrm{mmol})$ were added. After stirring at $-78^{\circ} \mathrm{C}$ for 1 hour, the mixture was allowed to warm up to room temperature. After 3 hours, the mixture was diluted with $\mathrm{CH}_{2} \mathrm{Cl}_{2}$, washed with saturated $\mathrm{NH}_{4} \mathrm{Cl}$ aqueous solution, dried $\left(\mathrm{Na}_{2} \mathrm{SO}_{4}\right)$ and concentrated in vacuo. The residue was purfied by preparative TLC on silica gel, developing with hexane - ethyl acetate $(10: 1)$ to afford $64 \mathrm{mg}$ of 14 and $52 \mathrm{mg}$ (26\%) of 27 as a slightly yellow oil: IR (neat) $\mathrm{cm}^{-1} 3275,2925,2850,1575,1500 ;{ }^{1} \mathrm{H}$ NMR $\left(\mathrm{CDCl}_{3}\right) \delta$ $0.86(6 \mathrm{H}, \mathrm{d}, J=6.1 \mathrm{~Hz}), 2.10(1 \mathrm{H}, \mathrm{t}, J=2.6 \mathrm{~Hz}), 3.0(2 \mathrm{H}, \mathrm{m}), 3.36(2 \mathrm{H}, \mathrm{t}, J=6.6 \mathrm{~Hz}), 3.92(4 \mathrm{H}, \mathrm{s}), 5.56$ $(1 \mathrm{H}, \mathrm{dd}, J=8.5$ and $6.5 \mathrm{~Hz}), 7.3(3 \mathrm{H}, \mathrm{m}), 7.6(2 \mathrm{H}, \mathrm{m}) ; \mathrm{MS} m / z 536\left(\mathrm{M}^{+}\right)$. 


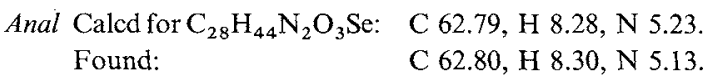

14-Methyl-1-(1-buten-3-ynyl- $O, N, N$-azoxy)-8-pentadecanone (24)

To a solution of $27(50 \mathrm{mg}, 0.093 \mathrm{mmol})$ in acetone $(2 \mathrm{ml})$ was added $2 \mathrm{~N} \mathrm{HCl}(0.2 \mathrm{ml})$ and the resulting mixture was stirred for 30 minutes at room temperature. After the mixture was neutralized with saturated $\mathrm{NaHCO}$ aqueous solution, the product was extracted with $\mathrm{CH}_{2} \mathrm{Cl}_{2}$. The extracts were dried $\left(\mathrm{Na}_{2} \mathrm{SO}_{4}\right)$ and concentrated in vacuo. The residue was diluted with $\mathrm{CH}_{2} \mathrm{Cl}_{2}(2 \mathrm{ml})$ and cooled to $0^{\circ} \mathrm{C}$. To the stirred solution was added $35 \% \mathrm{H}_{2} \mathrm{O}_{2}(0.3 \mathrm{ml})$. The resulting mixture was stirred for 30 minutes at $0^{\circ} \mathrm{C}$, warmed to room temperature, and stirred for 2 hours. After addition of water, the product was extracted with $\mathrm{CH}_{2} \mathrm{Cl}_{2}$. The extracts were dried $\left(\mathrm{Na}_{2} \mathrm{SO}_{4}\right)$ and concentrated in vacuo. The residue was purified by preparative TLC on silica gel, developing with hexane - ethyl acetate $(10: 1)$ to afford $25 \mathrm{mg}(80 \%)$ of $\mathbf{2 4}$, mp $58 \sim 59^{\circ} \mathrm{C}$ as white crystals: IR (neat) $\mathrm{cm}^{-1} 3300,3120,2930,2860,1705,1462 ;{ }^{1} \mathrm{H} \mathrm{NMR}\left(\mathrm{CDCl}_{3}\right) \delta$ $0.86(6 \mathrm{H}, \mathrm{d}, J=6.1 \mathrm{~Hz}), 2.39(4 \mathrm{H}, \mathrm{t}, J=7.1 \mathrm{~Hz}), 3.34(1 \mathrm{H}, \mathrm{d}, J=2.5 \mathrm{~Hz}), 3.54(2 \mathrm{H}, \mathrm{t}, J=6.7 \mathrm{~Hz}), 6.88(1 \mathrm{H}$, dd, $J=14.0$ and $2.5 \mathrm{~Hz}), 7.36(1 \mathrm{H}, \mathrm{d}, J=14.0 \mathrm{~Hz}) ; \mathrm{MS} m / z 317\left(\mathrm{M}^{+}-\mathrm{OH}\right)$.

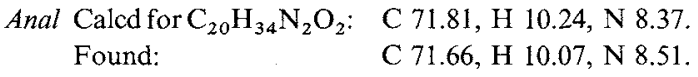

8,8-Ethylenedioxy-14-methyl-1-(2-phenyl-1-phenylselenoethyl- $O, N, N$-azoxy)pentadecane (28)

A solution of LDA prepared from $0.31 \mathrm{ml}(0.51 \mathrm{mmol})$ of $1.64 \mathrm{M} n$-butyllithium in hexane and diisopropylamine $(0.071 \mathrm{ml}, 0.51 \mathrm{mmol})$ in THF $(0.5 \mathrm{ml})$ was cooled to $-78^{\circ} \mathrm{C}$ and a solution of $14(230 \mathrm{mg}$, $0.46 \mathrm{mmol})$ in THF $(0.6 \mathrm{ml})$ was added dropwise. After 1 hour, HMPA $(0.16 \mathrm{ml}, 0.92 \mathrm{mmol})$ and benzyl bromide $(0.17 \mathrm{ml}, 1.43 \mathrm{mmol})$ were added. After stirring at $-78^{\circ} \mathrm{C}$ for 1 hour, the mixture was allowed to warm up to room temperature. After 20 hours, the mixture was diluted with $\mathrm{CH}_{2} \mathrm{Cl}_{2}$, washed with saturated $\mathrm{NH}_{4} \mathrm{Cl}$ aqueous solution, dried $\left(\mathrm{Na}_{2} \mathrm{SO}_{4}\right)$ and concentrated in vacuo. The residue was purified by preparative TLC on silica gel, developing with hexane - ethyl acetate $(10: 1)$ to afford $45 \mathrm{mg}$ of 14 and $48 \mathrm{mg}(18 \%)$ of 28 as a slightly yellow oil: IR (neat) $\mathrm{cm}^{-1} 3060,3030,2930,2860,1578,1490 ;{ }^{1} \mathrm{H}$ NMR $\left(\mathrm{CDCl}_{3}\right) \delta 0.86(6 \mathrm{H}, \mathrm{d}, J=6.1 \mathrm{~Hz}), 3.17(2 \mathrm{H}, \mathrm{t}, J=6.6 \mathrm{~Hz}), 3.42\left(2 \mathrm{H}, \mathrm{ABX}, J_{\mathrm{AB}}=14.3 \mathrm{~Hz}, J_{\mathrm{AX}}=5.9 \mathrm{~Hz}\right.$, $\left.J_{\mathrm{BX}}=9.6 \mathrm{~Hz}\right), 3.92(4 \mathrm{H}, \mathrm{s}), 5.68(1 \mathrm{H}, \mathrm{dd}, J=9.6$ and $5.9 \mathrm{~Hz}), 7.21(5 \mathrm{H}, \mathrm{s}), 7.3(3 \mathrm{H}, \mathrm{m}), 7.6(2 \mathrm{H}, \mathrm{m}) ; \mathrm{MS}$ $m / z 588\left(\mathrm{M}^{+}\right)$.

$\begin{array}{ll}\text { Anal Calcd for } \mathrm{C}_{32} \mathrm{H}_{48} \mathrm{~N}_{2} \mathrm{O}_{3} \mathrm{Se}: & \mathrm{C} 65.40, \mathrm{H} 8.23, \mathrm{~N} 4.77 . \\ & \mathrm{C} 65.14, \mathrm{H} 8.30, \mathrm{~N} 5.05\end{array}$

14-Methyl-1-(styryl- $O, N, N$-azoxy)-8-pentadecanone (23)

To a solution of $28(47 \mathrm{mg}, 0.08 \mathrm{mmol})$ in acetone $(2 \mathrm{ml})$ was added $2 \mathrm{~N} \mathrm{HCl}(0.2 \mathrm{ml})$ and the resulting mixture was stirred for 30 minutes at room temperature. After the mixture was neutralized with saturated $\mathrm{NaHCO}_{3}$ aqueous solution, the product was extracted with $\mathrm{CH}_{2} \mathrm{Cl}_{2}$. The extracts were dried $\left(\mathrm{Na}_{2} \mathrm{SO}_{4}\right)$ and concentrated in vacuo. The residue was diluted with $\mathrm{CH}_{2} \mathrm{Cl}_{2}(2 \mathrm{ml})$ and cooled to $0^{\circ} \mathrm{C}$. To the stirred solution was added $35 \% \mathrm{H}_{2} \mathrm{O}_{2}(0.3 \mathrm{ml})$. The resulting mixture was stirred for 30 minutes at $0^{\circ} \mathrm{C}$, warmed to room temperature, and stirred for 2 hours. After addition of water, the product was extracted with $\mathrm{CH}_{2} \mathrm{Cl}_{2}$. The extracts were dried $\left(\mathrm{Na}_{2} \mathrm{SO}_{4}\right)$ and concentrated in vacuo. The residue was purified by preparative TLC on silica gel, developing with hexane - ethyl acetate $(10: 1)$ to afford $25 \mathrm{mg}(81 \%)$ of 23 , mp $63 \sim 65^{\circ} \mathrm{C}$ as white crystals: IR (neat) $\mathrm{cm}^{-1} 2930,2860,1702,1640,1460 ;{ }^{1} \mathrm{H} \mathrm{NMR}\left(\mathrm{CDCl}_{3}\right) \delta 0.85$ $(6 \mathrm{H}, \mathrm{d}, J=6.1 \mathrm{~Hz}), 2.39(4 \mathrm{H}, \mathrm{t}, J=7.1 \mathrm{~Hz}), 3.60(2 \mathrm{H}, \mathrm{t}, J=6.9 \mathrm{~Hz}), 7.46(5 \mathrm{H}, \mathrm{m}), 7.54(1 \mathrm{H}, \mathrm{d}, J=14.0 \mathrm{~Hz})$, $7.82(1 \mathrm{H}, \mathrm{d}, J=14.0 \mathrm{~Hz}) ; \mathrm{MS} m / z 386\left(\mathrm{M}^{+}\right)$.

$$
\begin{array}{ll}
\text { Anal Calcd for } \mathrm{C}_{24} \mathrm{H}_{38} \mathrm{~N}_{2} \mathrm{O}_{2}: & \text { C 74.57, H 9.91, N 7.25. } \\
\text { Found: } & \text { C 74.57, H 9.83, N 7.00. }
\end{array}
$$

\section{4-Methyl-1-(methyl- $O, N, N$-azoxy)-8-pentadecanone (19)}

To a solution of $12(65 \mathrm{mg}, 0.19 \mathrm{mmol})$ in acetone $(2 \mathrm{ml})$ was added $2 \mathrm{~N} \mathrm{HCl}(0.2 \mathrm{ml})$ and the resulting mixture was stirred for 30 minutes at room temperature. After the mixture was neutralized with saturated $\mathrm{NaHCO}_{3}$ aqueous solution, the product was extracted with $\mathrm{CH}_{2} \mathrm{Cl}_{2}$. The extracts were dried $\left(\mathrm{Na}_{2} \mathrm{SO}_{4}\right)$ and concentrated in vacuo. The residue was purified by column chromatography on silica gel, eluting with hexane - ethyl acetate $(10: 1)$ to afford $49 \mathrm{mg}(87 \%)$ of 19 as a colorless oil: IR (neat), $\mathrm{cm}^{-1} 2920,2850$, 
1705,$1508 ;{ }^{1} \mathrm{H}$ NMR $\left(\mathrm{CDCl}_{3}\right) \delta 0.86(6 \mathrm{H}, \mathrm{d}, J=6.1 \mathrm{~Hz}), 2.39(4 \mathrm{H}, \mathrm{t}, J=7.0 \mathrm{~Hz}), 3.39(2 \mathrm{H}$, br t, $J=6.9 \mathrm{~Hz})$, $4.05\left(3 \mathrm{H}\right.$, br s); MS $m / z 281\left(\mathrm{M}^{+}-\mathrm{OH}\right)$.

Anal Calcd for $\mathrm{C}_{17} \mathrm{H}_{34} \mathrm{~N}_{2} \mathrm{O}_{2}$ : C 68.41, H 11.48, N 9.39.

Found:

C 68.35, H 1 1.45, N 9.13.

8,8-Ethylenedioxy-14-methyl-1-(ethyl- $O, N, N$-azoxy)pentadecane (11)

To a vigorously stirred suspension of $9(3 \mathrm{~g}, 8.07 \mathrm{mmol})$ and $\mathrm{NaHCO}_{3}(6 \mathrm{~g}, 71.4 \mathrm{mmol})$ in dry ethyl ether $(15 \mathrm{ml})$ at $-40^{\circ} \mathrm{C}$ under nitrogen was added dropwise a solution of $\mathrm{N}_{2} \mathrm{O}_{4}(5.5 \mathrm{~g}, 59.8 \mathrm{mmol})$ in ethyl ether $(4 \mathrm{ml})$. After the addition was complete, the reaction mixture was stirred at $-20^{\circ} \mathrm{C}$ for 30 minutes and then poured into ice-saturated $\mathrm{NaHCO}_{3}$ aqueous solution. The ethereal layer was separated, dried $\left(\mathrm{Na}_{2} \mathrm{SO}_{4}\right)$ and concentrated in vacuo under $30^{\circ} \mathrm{C}$ to afford the $N$-nitroso product $(\mathbf{1 0})$ as yellow oil, which was used for the next reaction without further purification. To a suspension of potassium tert-butoxide $(1.36 \mathrm{~g}$, $12.1 \mathrm{mmol})$ in ethyl ether $(20 \mathrm{ml})$ at $-40^{\circ} \mathrm{C}$ under nitrogen was added dropwise a solution of the $N$-nitroso product in ethyl ether $(6 \mathrm{ml})$. After the mixture was stirred at $-25^{\circ} \mathrm{C}$ for 1 hour, the solvent was removed under $0^{\circ} \mathrm{C}$ in vacuo. To the residue were added HMPA $(20 \mathrm{ml})$ and ethyl iodide $(5 \mathrm{ml}, 62.5 \mathrm{mmol})$ and then the resulting mixture was stirred at room temperature for 20 hours. The solvents were removed in vacuo and the residue was diluted with $\mathrm{CH}_{2} \mathrm{Cl}_{2}$. The solution was washed with water, dried $\left(\mathrm{Na}_{2} \mathrm{SO}_{2}\right)$ and concentrated in vacuo. The residue was purified by column chromatography on silica gel, eluting with hexane - ethyl acetate $(10: 1)$ to afford $1.1 \mathrm{~g}(38 \%)$ of 11 as a slightly yellow oil: IR (neat) $\mathrm{cm}^{-1} 2930$, 2860,$1510 ;{ }^{1} \mathrm{H} \mathrm{NMR}\left(\mathrm{CDCl}_{3}\right) \delta 0.86(6 \mathrm{H}, \mathrm{d}, J=6.1 \mathrm{~Hz}), 1.51(3 \mathrm{H}, \mathrm{t}, J=7.4 \mathrm{~Hz}), 3.39(2 \mathrm{H}, \mathrm{t}, J=6.9 \mathrm{~Hz})$, $3.92(4 \mathrm{H}, \mathrm{s}), 4.19$ ( $2 \mathrm{H}, \mathrm{q}, J=7.4 \mathrm{~Hz}) ; \mathrm{MS} m / z 339\left(\mathrm{M}^{+}-\mathrm{OH}\right)$.

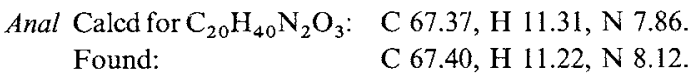

14-Methyl-1-(ethyl- $O, N, N$-azoxy)-8-pentadecanone (20)

To a solution of $11(55 \mathrm{mg}, 0.15 \mathrm{mmol})$ in acetone $(2 \mathrm{ml})$ was added $2 \mathrm{~N} \mathrm{HCl}(0.2 \mathrm{ml})$ and the resulting mixture was stirred for 30 minutes at room temperature. After the mixture was neutralized with saturated $\mathrm{NaHCO}_{3}$ aqueous solution, the product was extracted with $\mathrm{CH}_{2} \mathrm{Cl}_{2}$. The extracts. were dried $\left(\mathrm{Na}_{2} \mathrm{SO}_{4}\right)$ and concentrated in vacuo. The residue was purified by column chromatography on silica gel, eluting with hexane - ethyl acetate $(10: 1)$ to afford $41 \mathrm{mg}(85 \%)$ of $\mathbf{2 0}$ as a colorless oil: IR (neat) $\mathrm{cm}^{-1} 2930,2860$, 1705,$1502 ;{ }^{1} \mathrm{H} \mathrm{NMR}\left(\mathrm{CDCl}_{3}\right) \delta 0.86(6 \mathrm{H}, \mathrm{d}, J=6.1 \mathrm{~Hz}), 1.51(3 \mathrm{H}, \mathrm{t}, J=7.4 \mathrm{~Hz}), 2.39(4 \mathrm{H}, \mathrm{t}, J=7.1 \mathrm{~Hz})$, $3.39(2 \mathrm{H}$, br t, $J=6.9 \mathrm{~Hz}), 4.19(2 \mathrm{H}$, br q, $J=7.4 \mathrm{~Hz})$; MS $m / z 295\left(\mathrm{M}^{+}-\mathrm{OH}\right)$.

$\begin{array}{ll}\text { Anal Caled for } \mathrm{C}_{18} \mathrm{H}_{36} \mathrm{~N}_{2} \mathrm{O}_{2}: & \mathrm{C} 69.18, \mathrm{H} 11.61, \mathrm{~N} 8.96 . \\ \text { Found: } & \text { C } 69.24, \mathrm{H} 11.66, \mathrm{~N} 8.82 .\end{array}$

8-Hydroxy-14-methyl-1-(vinyl- $O, N, N$-azoxy)pentadecane (16)

To a solution of jietacin $\mathrm{A}(1)(46 \mathrm{mg}, 0.15 \mathrm{mmol})$ in ethanol $(2 \mathrm{ml})$ at $0^{\circ} \mathrm{C}$ was added $\mathrm{NaBH}_{4}(5 \mathrm{mg}$, $0.13 \mathrm{mmol}$ ) and the resulting mixture was stirred for 2 hours. After the reaction was quenched by addition of acetic acid, water was added to the mixture and the product was extracted with $\mathrm{CH}_{2} \mathrm{Cl}_{2}$. The extracts were dried $\left(\mathrm{Na}_{2} \mathrm{SO}_{4}\right)$ and concentrated in vacuo. The residue was purified by column chromatography on silica gel, eluting with hexane - ethyl acetate $(5: 1)$ to afford $38 \mathrm{mg}(82 \%)$ of 16 as a colorless oil: IR (neat) $\mathrm{cm}^{-1} 3400,2940,2860,1470 ;{ }^{1} \mathrm{H} \mathrm{NMR}\left(\mathrm{CDCl}_{3}\right) \delta 0.86(6 \mathrm{H}, \mathrm{d}, J=6.1 \mathrm{~Hz}), 3.55(2 \mathrm{H}, \mathrm{t}, J=7.1 \mathrm{~Hz}), 5.50$ $(1 \mathrm{H}, \mathrm{d}, J=7.7 \mathrm{~Hz}), 6.41(1 \mathrm{H}, \mathrm{d}, J=15.3 \mathrm{~Hz}), 7.11(1 \mathrm{H}, \mathrm{dd}, J=15.3$ and $7.7 \mathrm{~Hz}) ; \mathrm{MS} m / z 295\left(\mathrm{M}^{+}-\mathrm{OH}\right)$.

Anal Calcd for $\mathrm{C}_{18} \mathrm{H}_{36} \mathrm{~N}_{2} \mathrm{O}_{2}: \quad \mathrm{C} 69.18, \mathrm{H}$ 11.61, N 8.96.

Found:

C 69.32, H 11.71, N 9.00.

Ẹthyl 6-Methylheptyl Carbamate (29)

To a stirred solution of 6-methylheptylamine $(895 \mathrm{ml}, 6.92 \mathrm{mmol})$ in $\mathrm{CHCl}_{3}(10 \mathrm{ml})$ at $0^{\circ} \mathrm{C}$ were added pyridine $(1.5 \mathrm{ml}, 18.5 \mathrm{mmol})$ and ethyl chloroformate $(1.21 \mathrm{ml}, 12.7 \mathrm{mmol})$. Stirring was continued for 1 hour and then the mixture was poured into ice-saturated $\mathrm{NaHCO}_{3}$ aqueous solution. The product was extracted with $\mathrm{CH}_{2} \mathrm{Cl}_{2}$, dried $\left(\mathrm{Na}_{2} \mathrm{SO}_{4}\right)$ and concentrated in vacuo. The residue was purified by column chromatography on silica gel, eluting with hexane-ethyl acetate $(1: 1)$ to afford $1.2 \mathrm{~g}(86 \%)$ of 29 as a colorless oil: IR (neat) $\mathrm{cm}^{-1} 3340,2960,2930,2870,1700,1535 ;{ }^{1} \mathrm{H}$ NMR $\left(\mathrm{CDCl}_{3}\right) \delta 0.86(6 \mathrm{H}, \mathrm{d}$, 
$J=6.1 \mathrm{~Hz}), 1.24(3 \mathrm{H}, \mathrm{t}, J=7.1 \mathrm{~Hz}), 3.16(2 \mathrm{H}, \mathrm{q}, J=6.1 \mathrm{~Hz}), 4.11(2 \mathrm{H}, \mathrm{q}, J=7.1 \mathrm{~Hz}) ; \mathrm{MS} m / z 201\left(\mathrm{M}^{+}\right)$. Anal Calcd for $\mathrm{C}_{11} \mathrm{H}_{23} \mathrm{NO}_{2}$ : C 65.63, $\mathrm{H} 11.52, \mathrm{~N} 6.96$. Found:

C $65.74, \mathrm{H} 11.64, \mathrm{~N} 6.89$.

6-Methyl-1-(methyl- $O, N, N$-azoxy)heptane (30)

To a vigorously stirred suspension of $29(3 \mathrm{~g}, 14.9 \mathrm{mmol})$ and $\mathrm{NaHCO}_{3}(6 \mathrm{~g}, 71.4 \mathrm{mmol})$ in dry ethyl ether $(15 \mathrm{ml})$ at $-40^{\circ} \mathrm{C}$ under nitrogen was added dropwise a solution of $\mathrm{N}_{2} \mathrm{O}_{4}(5.9 \mathrm{~g}, 64.1 \mathrm{mmol})$ in ethyl ether $(4 \mathrm{ml})$. After the addition was complete, the reaction mixture was stirred at $-20^{\circ} \mathrm{C}$ for 30 minutes and then poured into ice-saturated $\mathrm{NaHCO}_{3}$ aqueous solution. The ethereal layer was separated, dried $\left(\mathrm{Na}_{2} \mathrm{SO}_{4}\right)$ and concentrated in vacuo under $30^{\circ} \mathrm{C}$ to afford the $N$-nitroso product as yellow oil, which was used for the next reaction without further purification. To a suspension of potassium tert-butoxide $(3.43 \mathrm{~g}$, $30.6 \mathrm{mmol})$ in ethyl ether $(12 \mathrm{ml})$ at $-40^{\circ} \mathrm{C}$ under nitrogen was added dropwise a solution of the $N$-nitroso product in ethyl ether $(5 \mathrm{ml})$. After the mixture was stirred at $-25^{\circ} \mathrm{C}$ for 1 hour, the solvent was removed under $0^{\circ} \mathrm{C}$ in vacuo. To the residue were added HMPA $(25 \mathrm{ml})$ and methyl iodide $(6 \mathrm{ml}, 96.4 \mathrm{mmol})$ and then the resulting mixture was stirred at room temperature for 20 hours. The solvents were removed in vacuo and the residue was diluted with $\mathrm{CH}_{2} \mathrm{Cl}_{2}$. The solution was washed with water, dried $\left(\mathrm{Na}_{2} \mathrm{SO}_{4}\right)$ and concentrated in vacuo. The residue was purified by column chromatography on silica gel, eluting with hexane - ethyl acetate $(10: 1)$ to afford $975 \mathrm{mg}(38 \%)$ of $\mathbf{3 0}$ as a slightly yellow oil: IR (neat) $\mathrm{cm}^{-1} 2950$, $2920,2850,1512 ;{ }^{1} \mathrm{H}$ NMR $\left(\mathrm{CDCl}_{3}\right) \delta 0.87(6 \mathrm{H}, \mathrm{d}, J=6.1 \mathrm{~Hz}), 3.39(2 \mathrm{H}, \mathrm{dt}, J=6.9$ and $1.5 \mathrm{~Hz}), 4.06(3 \mathrm{H}$, $\mathrm{t}, J=1.5 \mathrm{~Hz}) ; \mathrm{MS} m / z 155\left(\mathrm{M}^{+}-\mathrm{OH}\right)$.

Anal Caled for $\mathrm{C}_{9} \mathrm{H}_{20} \mathrm{~N}_{2} \mathrm{O}: \quad \mathrm{C} 62.75, \mathrm{H} 11.70, \mathrm{~N} 16.26$. Found:

C $62.84, \mathrm{H} 11.93, \mathrm{~N} 15.97$.

6-Methyl-1-(phenylselenomethyl-O,N,N-azoxy)heptane (31)

A solution of LDA was prepared by adding $2.13 \mathrm{ml}(3.49 \mathrm{mmol})$ of $1.64 \mathrm{M} n$-butyllithium in hexane to diisopropylamine $(0.49 \mathrm{ml}, 3.50 \mathrm{mmol})$ in THF $(4 \mathrm{ml})$. The solution was stirred and cooled to $0^{\circ} \mathrm{C}$, and a solution of $30(550 \mathrm{mg}, 3.19 \mathrm{mmol})$ in THF $(4 \mathrm{ml})$ was added. After 30 minutes, a solution of diphenyl diselenide $(1.49 \mathrm{~g}, 4.77 \mathrm{mmol})$ and HMPA $(0.61 \mathrm{ml}, 3.51 \mathrm{mmol})$ in THF $(0.6 \mathrm{ml})$ was added to the resulting solution of the carbanion. Stirring was continued for 90 minutes at $0^{\circ} \mathrm{C}$. The reaction mixture was diluted with $\mathrm{CH}_{2} \mathrm{Cl}_{2}$, washed with saturated $\mathrm{NH}_{4} \mathrm{Cl}$ aqueous solution, dried $\left(\mathrm{Na}_{2} \mathrm{SO}_{4}\right)$, and concentrated in vacuo. The residue was purified by column chromatography on silica gel, eluting with hexane-ethyl acetate $(10 ; 1)$ to afford $570 \mathrm{mg}(55 \%)$ of $\mathbf{3 1}$ as a slightly yellow oil: IR (neat) $\mathrm{cm}^{-1} 3050,2940,2920,2850,1575,1495$; ${ }^{1} \mathrm{H} \mathrm{NMR}\left(\mathrm{CDCl}_{3}\right) \delta 0.87(6 \mathrm{H}, \mathrm{d}, J=6.8 \mathrm{~Hz}), 3.36(2 \mathrm{H}, \mathrm{t}, J=7.3 \mathrm{~Hz}), 5.39(2 \mathrm{H}, \mathrm{s}), 7.3(3 \mathrm{H}, \mathrm{m}), 7.6(2 \mathrm{H}$, $\mathrm{m}) ; \mathrm{MS} m / z 171\left(\mathrm{M}^{+}-\mathrm{SePh}\right)$.

Anal Calcd for $\mathrm{C}_{15} \mathrm{H}_{24} \mathrm{~N}_{2} \mathrm{OSe}$ : C 55.04, H 7.39, N 8.56. Found: $\quad$ C $55.14, \mathrm{H} 7.32, \mathrm{~N} 8.46$.

6-Methyl-1-(1-phenylselenoethyl- $O, N, N$-azoxy)heptane (32)

A solution of LDA prepared from $1.04 \mathrm{ml}(1.71 \mathrm{mmol})$ of $1.64 \mathrm{M} n$-butyllithium in hexane and diisopropylamine $(0.24 \mathrm{ml}, 1.71 \mathrm{mmol})$ in THF $(2 \mathrm{ml})$ was cooled to $-78^{\circ} \mathrm{C}$ and a solution of $31(510 \mathrm{mg}$, $1.56 \mathrm{mmol})$ in THF $(2 \mathrm{ml})$ was added dropwise. After 1 hour, HMPA $(0.41 \mathrm{ml}, 2.36 \mathrm{mmol})$ and methyl iodide $(0.31 \mathrm{ml}, 4.98 \mathrm{mmol})$ were added. After stirring at $-78^{\circ} \mathrm{C}$ for 1 hour, the mixture was allowed to warm up to room temperature. After 2 hours, the mixture was diluted with $\mathrm{CH}_{2} \mathrm{Cl}_{2}$, washed with saturated $\mathrm{NH}_{4} \mathrm{Cl}$ aqueous solution, dried $\left(\mathrm{Na}_{2} \mathrm{SO}_{4}\right)$ and concentrated in vacuo. The residue was purified by column chromatography on silica gel, eluting with hexane - ethyl acetate $(10: 1)$ to afford $390 \mathrm{mg}(73 \%)$ of $\mathbf{3 2}$ as a slightly yellow oil: IR (neat) $\mathrm{cm}^{-1} 3040,2930,2900,2840,1570,1492 ;{ }^{1} \mathrm{H}$ NMR $\left(\mathrm{CDCl}_{3}\right) \delta 0.86(6 \mathrm{H}$, d, $J=6.4 \mathrm{~Hz}), 1.84(3 \mathrm{H}, d, J=6.9 \mathrm{~Hz}), 3.30(2 \mathrm{H}, \mathrm{t}, J=6.7 \mathrm{~Hz}), 5.64(1 \mathrm{H}, \mathrm{q}, J=6.9 \mathrm{~Hz}), 7.3(3 \mathrm{H}, \mathrm{m}), 7.6$ $(2 \mathrm{H}, \mathrm{m}) ; \mathrm{MS} m / z 341\left(\mathrm{M}^{+}\right)$.

$\begin{array}{ll}\text { Anal Calcd for } \mathrm{C}_{16} \mathrm{H}_{26} \mathrm{~N}_{2} \mathrm{OSe}: & \text { C } 56.30, \mathrm{H} 7.68, \mathrm{~N} 8.21 . \\ \text { Found: } & \text { C } 56.42, \mathrm{H} 7.38, \mathrm{~N} 7.92 .\end{array}$

6-Methyl-1-(vinyl- $O, N, N$-azoxy)heptane (18)

To a stirred solution of $32(360 \mathrm{mg}, 1.05 \mathrm{mmol})$ in $\mathrm{CH}_{2} \mathrm{Cl}_{2}(5 \mathrm{ml})$ at $0^{\circ} \mathrm{C}$ was added $35 \% \mathrm{H}_{2} \mathrm{O}_{2}(0.5 \mathrm{ml})$. The resulting mixture was stirred for 30 minutes at $0^{\circ} \mathrm{C}$, warmed to room temperature, and stirred for 2 
hours. After addition of water, the product was extracted with $\mathrm{CH}_{2} \mathrm{Cl}_{2}$. The extracts were dried $\left(\mathrm{Na}_{2} \mathrm{SO}_{4}\right)$ and concentrated in vacuo. The residue was purified by column chromatography on silica gel, eluting with hexane - ethyl acetate (20:1) to afford $170 \mathrm{mg}(87 \%)$ of 18 as a colorless oil: IR (neat) $\mathrm{cm}^{-1} 3080,2930$, $2900,2850,1635,1465 ;{ }^{1} \mathrm{H} \mathrm{NMR}\left(\mathrm{CDCl}_{3}\right) \delta 0.87(6 \mathrm{H}, \mathrm{d}, J=6.1 \mathrm{~Hz}), 3.55(2 \mathrm{H}, \mathrm{t}, J=6.9 \mathrm{~Hz}), 5.49(1 \mathrm{H}$, $\mathrm{t}, J=7.6 \mathrm{~Hz}), 6.41(1 \mathrm{H}, \mathrm{d}, J=15.0 \mathrm{~Hz}), 7.12(\mathrm{lH}, \mathrm{dd}, J=15.0$ and $7.6 \mathrm{~Hz}) ; \mathrm{MS} m / z 167\left(\mathrm{M}^{+}-\mathrm{OH}\right)$.

Anal Calcd for $\mathrm{C}_{10} \mathrm{H}_{20} \mathrm{~N}_{2} \mathrm{O}:$ C $65.18, \mathrm{H} 10.94, \mathrm{~N} 15.20$. Found:

C 65.18, H 10.97 , N 15.19 .

Nematocidal Activity

The nematocidal activity against the pine wood nematode $B$. lignicolus was assayed as described previously. ${ }^{7)}$

\section{References}

1) Ōmura, S.; K. Otoguro, N. Imamura, H. Kuga, Y. Takahashi, R. Masuma, Y. Tanaka, H. TanaKa, S. Xue-hut \& Y. EN-TAI: Jietacins A and B, new nematocidal antibiotics from a Streptomyces sp. Taxonomy, isolation, and physico-chemical and biological properties. J. Antibiotics 40: 623 629, 1987

2) Imamura, N.; H. Kuga, K. Otoguro, H. TANaKa \& S. OMura: Structures of jietacins: Unique $\alpha, \beta$-unsaturated azoxy antibiotics. J. Antibiotics 42: 156 158, 1989

3) Bestmann, H. J.; O. V. Vostrowsky \& W. Stransky: Eine stereoselektive synthese des( $Z$ )-7,8-epoxy-2methyloctadecans. Chem. Ber. 109: 3375 3378, 1976

4) Moss, R. A.; M. J. LANDon, K. M. Luchter \& A. Mamantov: A flexible and directed synthesis of azoxyalkanes. J. Am. Chem. Soc. 94: 4392 4394, 1972

5) Moss, R. A. \& G. M. LovE: $\alpha$-(Proximal)-azoxyalkyl carbanions. Tetrahedron Lett. 1973: 4701 4704, 1973

6) REICH, H. J.; J. M. RENGA \& I. L. ReICH: Organoselenium chemistry. Conversion of ketones to enones by selenoxide syn elimination. J. Am. Chem. Soc. 97: 5434 5447, 1975

7) Otoguro, K.; Z.-X. Liu, K. Fukuda, Y. Li, Y. Iwai, H. Tanaka \& S. OMura: Screening for new nematocidal substances of microbial origin by a new method using the pine wood nematode. J. Antibiotics 41: $573 \sim 575$, 1988 